Original article

\title{
COMPARATIVE STUDY OF HEPARIN- AND TOLUIDINE BLUE POSITIVE MAST CELLS IN PORCINE LUMBAR SPINAL GANGLIA
}

\author{
A. VODENICHAROV ${ }^{1}$, N. TSANDEV ${ }^{1}$, G. KOSTADINOV $^{1}$ \\ \& I. STEFANOV ${ }^{2}$ \\ ${ }^{1}$ Department of Veterinary Anatomy, Histology and Embryology, Faculty of Veteri- \\ nary Medicine; ${ }^{2}$ Faculty of Medicine, Trakia University, Stara Zagora, Bulgaria
}

\section{Summary}

Vodenicharov, A., N. Tsandev, G. Kostadinov \& I. Stefanov, 2018. Comparative study of heparin- and toluidine blue positive mast cells in porcine lumbar spinal ganglia. Bulg. $J$. Vet. Med., 21, No 4, 391-396.

\begin{abstract}
In the present study, toluidine blue for metachromasia and berberine sulfate for heparin fluorescence were used to determine the localisation and distribution of mast cells as well as the percent of heparin-positive cells $(\mathrm{MCH})$ in normal lumbar spinal ganglia (dorsal root ganglia) of domestic swine. Mast cells density was established after estimating the number of these cells per ganglion. Mast cells with metachromasia (MCTB) were observed predominantly in the ganglion capsule near the blood

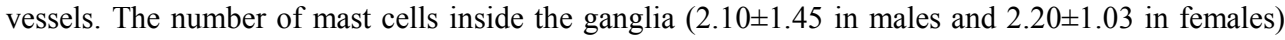
was significantly lower than in the capsule $(13.30 \pm 1.95$ in males and $13.60 \pm 2.42$ in females $)$ in both genders $(\mathrm{P}<0.001)$. Sexual dimorphism of the studied parameters was not established except for the slightly higher number of mast cells localised inside the left spinal ganglia of females than in males $(\mathrm{P}<0.05)$. The localisation of heparin-positive mast cells and the ratio between them and mast cells stained with toluidine blue (almost 2:1) was also determined. The percentage of heparin-positive mast cells in the ganglion capsule was $4 \%$, whereas inside the ganglion $-40 \%$.
\end{abstract}

Key words: heparin, mast cells, pig, spinal ganglia, toluidine blue

\section{INTRODUCTION}

Sensory ganglia contain the cell bodies of primary afferent neurons that transmit sensory information from the periphery into the central nervous system (CNS), and also send collaterals to prevertebral sympathetic ganglia (Aldskogius et al., 1986). Most of the sensory signals from the body are conveyed into CNS by dorsal root (spinal) ganglia. These structures are located near the entrance of dorsal roots into the spinal cord, and are not part of the CNS. Dorsal root ganglia (DRG) neurons have a single axon that forms a T-shaped bifurcation; the long branch extends into the periphery and forms the sensory endings in the skin, muscle, viscera and other 
organs, and the short branch enters the spinal cord (Hanami, 2005).

Mast cells are members of the immune system with properties of both the innate and acquired immune response (Galli et al., 2005). They are characterised by a large complement of secretory granules which store a wide variety of mediators, including biogenic amines, neuropeptides, cytokines, sulfated proteoglycans and neutral proteases (Johnson \& Krenger, 1992; Silver et al., 1996; Galli et al., 2005). When released in the CNS, mast cell secretory products can alter the function of both neural (Khalil et al., 2004) and vascular (Esposito et al., 2001) elements.

There is abundant evidence that the mast cells in the nervous system, like those in other parts of the organism, contain heparin and that they are able to synthesise, store, and, under certain conditions, release biogenic amines (Olsson, 1968). The heparin component of the mast cells may play a role in the enzymatic breakdown of lipids in the myelin sheaths. It is well known that peripheral nerve injury induces activation of resident immune cells as well as recruitment of inflammatory cells to the nerve (Moalem \& Tracey, 2006; Scholz \& Woolf, 2007).

However, there is no data about the proportion of heparin positive mast cells from the total number of the toluidine blue staining detected mast cells in mammalian resp. porcine somatic and autonomic ganglia. In that view, the role of heparinpositive mast cells in the function of these ganglia including lumbar ganglia, has not yet been established.

Having in mind the importance of mast cells in the nervous system function, we aimed to establish the mast cell localisation and density and the percentage of heparin positive mast cells within porcine lumbar spinal ganglia for better under- standing their role in these specific neuronal structures.

\section{MATERIALS AND METHODS}

\section{Animals}

The right and left $5^{\text {th }}$ lumbar spinal ganglia were obtained from 12 (6 male and 6 female) six months old crossbred pigs (Landrace $\times$ Bulgarian White), 96-100 kg body weight. Animals were slaughtered for meat consumption in a slaughterhouse according to Bulgarian laws.

Histochemical detection of heparin and metachromasia in mast cells

Whole ganglia were carefully removed from the longitudinally dissected animal corpses and immediately fixed by immersion in Carnoy's liquid for 4 hours, at room temperature. After that, they were dehydrated in ascending ethanol series, cleared in xylene and embedded in paraffin. Three serial longitudinal sections of 6 $\mu \mathrm{m}$ from the largest part of every lumbar ganglion (with peripheral and central parts of pseudounipolar neurons as well) were firstly stained with $0.02 \%$ aqueous solution of berberine sulfate (Sigma, Steinheim, Germany) $\mathrm{pH} 4$ for further comparison with a subsequent toluidine blue staining (Xu et al., 1993). For this purpose, the berberine stained sections were mounted by glycerol, studied immediately with fluorescence microscope (LEICA DM 5000 B, Exc. filter BP 490, Suppr. filter LP 515, software LEICA Application Suite v. 4.1.0) and three suitable fields from every section were photographied with digital camera (LEICA DFC 420C). Then, the cover glasses were demounted by distilled water and stained with toluidine blue (Riedel de Haën, AG, Seelze, Germany) in McIlvane's buffer with $\mathrm{pH} 3$ 
(Pearce, 1960), dehydrated in ascending ethanol series, cleared in xylene, and mounted with Entellan (Merck. Darmstadt, Germany). The same areas were rephotographied. The number of berberineand toluidine blue positive mast cells per field $(\times 10-$ two fields per section) was compared and the percentage of berberine positive i.e. heparin containing mast cell in the capsule and inside the ganglions was evaluated. Microscopic assessment of the fluorescence was scored as absent (0), weak $(+)$ and strong $(++)$ (Stefanov et al., 2016).

\section{Statistical analysis}

Five longitudinal sections from each ganglion stained with toluidine blue were used to determine the mast cells number per section. Numbers of toluidine blue positive mast cells per ganglion (in the capsule and inside the ganglia) were pre- sented as mean \pm standard deviation (SD). Statistical data processing was done by the Student's t-test. The difference was considered significant at $\mathrm{P}<0.05$.

\section{RESULTS}

The light microscopic observations after TB staining showed that the major part of mast cells $(86 \%)$ was localised in the ganglion's capsule situated predominantly near the blood vessels (Table 1; Fig. 1). It should be noted that the number of mast cells within the ganglia was much lower than that in the capsule $(\mathrm{P}<0.001)$ in both genders (Table 1). Mast cells were found in the vicinity of blood vessels, satellite cells and near the nerve fibres (Fig. 2). Single mast cells were observed near the perikaryon of neurons and sheath of satellite cells (Fig. 3a).

Table 1. Number of mast cells (mean $\pm \mathrm{SD} ; \mathrm{n}=5$ ) stained with toluidine blue (MCTB) in porcine lumbar spinal ganglia. Heparin expression degree in mast cells and percentage of heparin positive mast cells in the same ganglia are also given

\begin{tabular}{|c|c|c|c|}
\hline $\begin{array}{l}\text { Mast cells } \\
\text { localisation }\end{array}$ & $\begin{array}{l}\text { MCsTB } \\
\text { number }\end{array}$ & $\begin{array}{l}\text { Heparin expression } \\
\text { in mast cells }\end{array}$ & $\begin{array}{l}\text { Heparin positive } \\
\text { mast cells }(\%)\end{array}$ \\
\hline \multicolumn{4}{|c|}{ Right spinal ganglia } \\
\hline \multicolumn{4}{|c|}{ - capsule } \\
\hline$\hat{\sigma}$ & $13.30 \pm 1.95$ & $++/+$ & 44 \\
\hline q & $13.60 \pm 2.42$ & $++/+$ & 45 \\
\hline \multicolumn{4}{|l|}{ - inside } \\
\hline$\hat{\jmath}$ & $2.10 \pm 1.45^{*}$ & $+/++$ & 40 \\
\hline q & $2.20 \pm 1.03$ & $+/++$ & 40 \\
\hline \multicolumn{4}{|c|}{ Left spinal ganglia } \\
\hline \multicolumn{4}{|c|}{ - capsule } \\
\hline ก & $13.20 \pm 1.81$ & $++/+$ & 45 \\
\hline q & $13.40 \pm 2.41$ & $++/+$ & 47 \\
\hline \multicolumn{4}{|l|}{ - inside } \\
\hline$\delta$ & $2.00 \pm 0.81 *$ & $+/++$ & 40 \\
\hline q & $2.10 \pm 0.99^{\mathrm{A}}$ & $+/++$ & 41 \\
\hline
\end{tabular}

$(++)$ strong, $(+)$ weak fluorescence in mast cells; $\hat{\sigma}-$ males, $q-$ females; $* \mathrm{P}<0.001-\mathrm{vs}$. the capsule of the ganglion; ${ }^{\mathrm{A}} \mathrm{P}<0.05-\mathrm{vs}$. left spinal ganglia of males. 


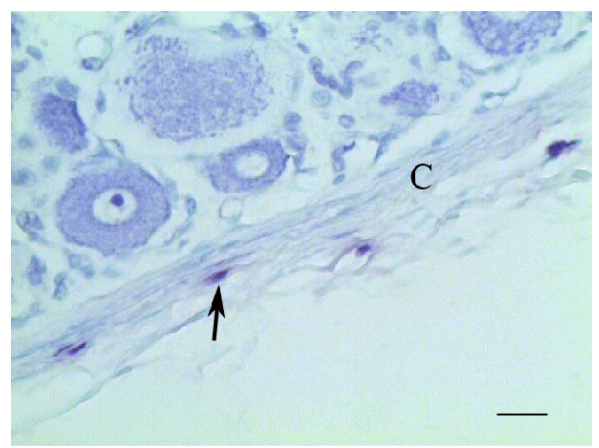

Fig. 1. MCTB (arrow) in the capsule (C) of left spinal ganglion of male pig. Toluidine blue staining. Bar $=25 \mu \mathrm{m}$.

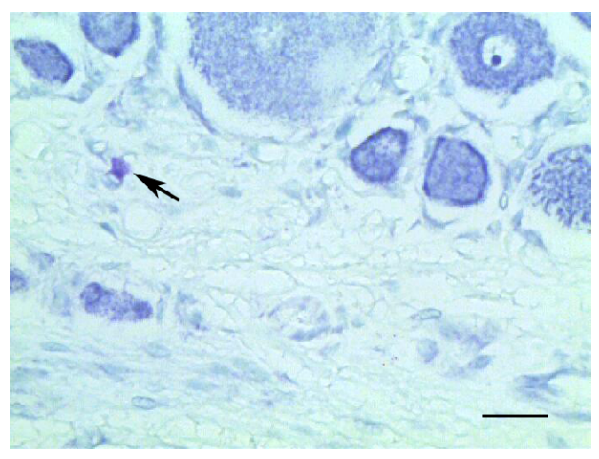

Fig. 2. MCTB (arrow) near the capillaries inside the left spinal ganglion of male pig. Toluidine blue staining. Bar $=30 \mu \mathrm{m}$.

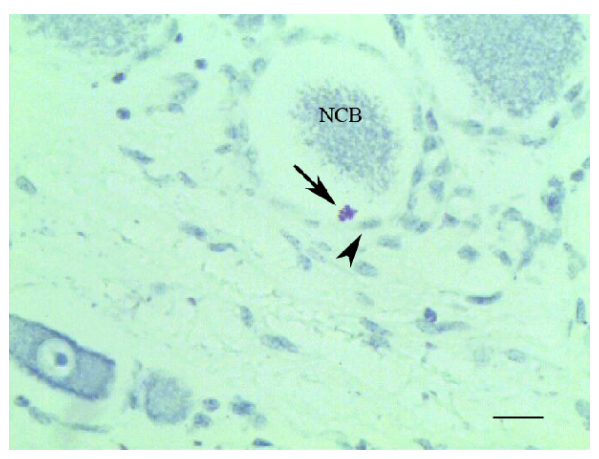

A
Sexual dimorphism of the studied parameters was not established except for the slightly higher number of mast cells localised inside the left spinal ganglia of females than in males $(\mathrm{P}<0.05)$.

The percentage of heparin-positive mast cells in the ganglion capsule was $45 \%$, whereas inside the ganglion it was 40\% (Fig. 3a,b; Table 1).

\section{DISCUSSION}

The present study provides original data for the presence of heparin containing i.e. berberine sulfate positive mast cells and their proportion from toluidine bluestained mast cells (MCsTB) in porcine lumbar sensory ganglia. Only mast cells' density within $\mathrm{L}_{5}$ was statistically analysed, as it participates in formation of sensory part of certain somatic nerves (Köning et al., 2009), and also supplies the urinary bladder with primary sensory neurons transmitting in that way the pain from the bladder (Drent, 2008; Bossowska et al., 2009).

Fig. 3. A. MCTB (arrow) between satellite cells (arrowhead) and neuron cell body (NCB) inside the right spinal ganglion of female pig (toluidine blue staining). B. The same mast cell (arrow) which is heparin positive. Arrowhead - satellite cell, NCB - neuron cell body (berberine sulfate staining). $\mathrm{Bar}=25 \mu \mathrm{m}$. 
Our results showed that regardless of the differences in the total number in both the capsule and inside of the ganglia, the percentages of heparin positive mast cells were similar. This fact allowed us assuming that the berberine positive mast cells, found both inside the ganglia and in their capsule, most probably influenced the function of the neurons, satellite cells and vascular cells via the sulfated glycosaminoglican heparin. In addition, as stated by Olsson (1968), the heparin component of the mast cells may play a role in the enzymatic breakdown of lipids in the myelin sheaths, also suggesting a role of these cells in the spinal ganglia.

The established percentage of heparin positive mast cells is similar to those found in the valves of the renal vein and its media in domestic pigs $-30 \%$ and $42 \%$ respectively (Vodenicharov, 2008a), but quite different in comparison with that observed in canine internal and external anal sphincters $-100 \%$ and $30 \%$, respectively (Stefanov, 2009). These findings are evidence for the tissue-dependent localisation of heparin containing mast cells.

A special attention should be paid to the mast cells' localisation between the perikaryon and glial ganglia cell (satellite cell) and within the capsule, with respect to the role of satellite glial cells in signal processing and transmission in sensory ganglia (Hanani, 2005). This allowed assuming that observed mast cells could participate in modulation of the function of above mentioned cells via certain ligands as endothelin-1, NADPH-d, resp. NO, histamine, VIP etc., established by us in porcine species (Vodenicharov et al., 2005; Vodenicharov, 2008b; Vodenicharov \& Bozhilova-Pastirova, 2010).

Both the present and previous results of ours (Vodenicharov \& Bozhilova-Pastirova, 2010) give us reason to presume that mast cells localised in autonomic and sensory ganglia, and in associated nerves as well, were actively involved via respective neurotransmitter ligands. In support of this hypothesis are the facts that satellite glial cells carry receptors for numerous neuroactive agents and participate in signal processing and transmission in sensory ganglia, as well as in pathological changes in the ganglia as affirmed by Hanani (2005).

In conclusion, heparin containing mast cells observed for the first time and estimated percentage from all mast cells found in porcine lumbar spinal ganglia allowed suggesting their active participation not only in the maintenance of the local microenvironment, but also in the function in the ganglia cells in general.

\section{REFERENCES}

Aldskogius, H., L. G. Elfvin \& C. A. Forsman, 1986. Primary sensory afferents in the inferior mesenteric ganglion and related nerves of the guinea pig. An experimental study with anterogradely transported wheat germ agglutinin-horseradish peroxidase conjugate. Journal of the Autonomic Nervous System, 15, 179-190.

Bossowska, A., R. Crayton, P. Radziszewski, Z. Kmiec \& M. Majewski, 2009. Distribution and neurochemical characterization of sensory dorsal root ganglia neurons supplying porcine urinary bladder. Journal of Physiology and Pharmacology, 60, Suppl 4, 77-81.

Drent, D., 2008. Bladder pain syndrome/interstitial cystitis. Continuing Medical Education, 35, 47-51.

Esposito, P., D. Gheorghe, K. Kandere, X. Pang, R. Connolly, S. Jacobson \& T. C. Theoharides, 2001. Acute stress increases permeability of the blood-brain barrier through activation of brain mast cells. Brain Research, 888, 117-127. 
Galli, S. J., S. Nakae \& M. Tsai, 2005. Mast cells in the development of adaptive immune responses. Nature Immunology, 6 , 135-142.

Hanami, M., 2005. Satellite glial cells in sensory ganglia: from form to function. Brain Research Reviews, 48, 457-486.

Johnson, D. \& W. Krenger, 1992. Interactions of mast cells with the nervous system recent advances. Neurochemistry Research, 17, 939-951.

Khalil, M. H., A. J. Silverman \& R. Silver, 2004. Mast cell mediators alter electrical activity of rat thalamic neurons. In: Keystone Symposium on Mast Cells in Physiology, Host Defense and Disease, Beyond IgE. Taos, New Mexico. p. 57.

Köning, H., H.-G. Liebich \& C. Červeny, 2009. Peripheral nervous system. In: Veterinary Anatomy of Domestic Animals, $4^{\text {th }}$ edn, eds. H. Köning \& H.-G. Liebich, Schauter, Stuttgard, Germany, pp. 499536.

Moalem, G. \& D. J. Tracey, 2006. Immune and inflammatory mechanisms in neuropathic pain. Brain Research Reviews, 51, 240-264.

Olsson, Y., 1968. Mast cells in the nervous system. International Review of Cytology, 24, 27-70.

Pearce, A., 1960. Histochemistry, $2^{\text {nd }}$ edn, J. and A. Churchill Ltd., London, p. 692.

Silver, R., A. J. Silverman, L. Vitkovic \& I. Lederhendler, 1996. Mast cells in the brain: Evidence and functional significance. Trends in Neuroscience, 19, 25-31.

Scholz, J. \& C. J. Woolf, 2007. The neuropathic pain triad: Neurons, immune cells and glia. Nature Neuroscice, 10, 13611368.

Stefanov, I. S., A. P. Vodenicharov \& N. Tsandev, 2009. Histochemical investigation of mast cells in the paranal sinus ( $\mathrm{Si}$ nus paranalis) of sexually immature dogs. Journal of Biomedical and Clinical Researches, 2, Suppl. 1, 22-25.
Stefanov, I. S., A. P. Vodenicharov, N. S. Tsandev \& D. Sevrieva, 2016. Histochemical study of heparin-positive mast cells in the terminal part of porcine ductus choledochus and papilla duodeni major. Anatomia Histologia Embryologia, 45, 386-391.

Vodenicharov, A., R. Leiser, M. Gulubova \& T. Vlaykova, 2005. Morphological and immunocytochemical investigations on mast cells in porcine ureter. Anatomia Histologia Embryologia, 34, 343-349.

Vodenicharov, A., 2008a. Mast cells in autonomic ganglia and nerves and in small renal hilar blood vessels in domestic swine. Bulgarian Journal of Veterinary Medicine, 11, 31-36.

Vodenicharov, A., 2008b. Endothelin positive mast cells in porcine renal artery and vein. Anatomia Histologia Embryologia, 37, 376-379.

Vodenicharov, A. \& A. Bozhilova-Pastirova, 2010. NADPH-d cells (mast cells) around and within the autonomic nerves of porcine renal hilus. Tissue and Cell, 42, 195197.

Xu, L, R., M. M. Caar, A. P. Bland \& G. A. Hall, 1993. Histochemistry and morphology of porcine mast cells. Histochemical Journal, 25, 516-522.

Paper received 25.11.2016; accepted for publication 06.02.2017

\section{Correspondence:}

Prof. Angel Vodenicharov Department of Veterinary Anatomy, Histology and Embryology, Faculty of Veterinary Medicine; Trakia University, 6000 Stara Zagora, Bulgaria email: angvod@uni-sz.bg 